\title{
Digital Gaming for Nutritional Education: A Survey on Preferences, Motives, and Needs of Children and Adolescents
}

Sophie Laura Holzmann ${ }^{1}$, MSc; Felicitas Dischl ${ }^{1}$, BSc; Hanna Schäfer ${ }^{2}$, MSc; Georg Groh², PhD; Hans Hauner ${ }^{1,3}$, MD; Christina Holzapfel ${ }^{1}$, PhD

\footnotetext{
${ }^{1}$ Institute for Nutritional Medicine, Else Kroener-Fresenius-Center for Nutritional Medicine, University Hospital "Klinikum rechts der Isar", Technical University of Munich, Munich, Germany

${ }^{2}$ Research Group Social Computing, Department of Informatics, Technical University of Munich, Garching, Germany

${ }^{3}$ Nutritional Medicine Unit, Institute for Food and Health, Technical University of Munich, Freising, Germany
}

\section{Corresponding Author:}

Christina Holzapfel, $\mathrm{PhD}$

Institute for Nutritional Medicine

Else Kroener-Fresenius-Center for Nutritional Medicine

University Hospital "Klinikum rechts der Isar", Technical University of Munich

Georg-Brauchle-Ring 62, 5th Floor

Munich, 80992

Germany

Phone: 498928924923

Fax: 498928924922

Email: christina.holzapfel@tum.de

\section{Abstract}

Background: Use of novel information and communication technologies are frequently discussed as promising tools to prevent and treat overweight and obesity in children and adolescents.

Objective: This survey aims to describe the preferences, motives, and needs of children and adolescents regarding nutrition and digital games.

Methods: We conducted a survey in 6 secondary schools in the southern region of Germany using a 43-item questionnaire. Questions referred to preferences, motives, and needs of children and adolescents regarding nutrition and digital games. In addition, knowledge regarding nutrition was assessed with 4 questions. We collected self-reported sociodemographic and anthropometric data. Descriptive statistical analyses were performed using SPSS.

Results: In total, 293 children and adolescents participated in the study, with ages 12-18 years (137 girls, $46.8 \%)$, weight 30.0-120.0 (mean 60.2 [SD 13.2]) kg, and height 1.4-2.0 (mean 1.7 [SD 0.1]) m. A total of 5.5\% (16/290) correctly answered the 4 questions regarding nutrition knowledge. Study participants acquired digital nutritional information primarily from the internet $(166 / 291,57.0 \%)$ and television $(97 / 291,33.3 \%)$, while school education $(161 / 291,55.3 \%)$ and parents or other adults $(209 / 291$, $71.8 \%$ ) were the most relevant nondigital information sources. Most participants $(242 / 283,85.5 \%)$ reported that they regularly play digital games. More than half $(144 / 236,61.0 \%)$ stated that they play digital games on a daily basis on their smartphones or tablets, and almost $70 \%(151 / 282,66.5 \%)$ reported playing digital games for $\leq 30$ minutes without any interruption. One-half of respondents $(144 / 280,51.4 \%)$ also stated that they were interested in receiving information about nutrition while playing digital games.

Conclusions: This survey suggests that nutrition knowledge in children and adolescents might be deficient. Most children and adolescents play digital games and express interest in acquiring nutritional information during digital gameplay. A digital game with a focus on sound nutrition could be a potential educational tool for imparting nutrition knowledge and promoting healthier nutrition behaviors in children and adolescents.

(JMIR Form Res 2019;3(1):e10284) doi: 10.2196/10284

\section{KEYWORDS}

adolescents; children; communication; motives; mobile phone; needs; nutrition; obesity; overweight; preferences; serious games; survey 


\section{Introduction}

\section{Overweight and Obesity in Children and Adolescents}

Overweight and obesity are major public health concerns worldwide [1]. In Germany, $15 \%$ of children and adolescents aged 3-17 years are overweight, while $6.3 \%$ are obese [2]. The number of children and adolescents with obesity, aged 5-19 years, has increased in most regions and countries from 1975 to 2016 [3]. The major cause of overweight and obesity is an energy imbalance between caloric intake and energy expenditure. An obesogenic environment, dominated by a Western diet high in energy-dense foods, is linked to obesity [1]. In addition, there is a growing trend toward a sedentary lifestyle [1,4]. Overweight and obesity require effective prevention and treatment strategies, especially in children and youths. At present, there is growing interest in exploring the potential of new information and communication technologies (ICTs), for example, mobile apps, for tackling the obesity epidemic. These novel tools are low cost, ubiquitous, and almost unlimitedly scalable. Studies have already demonstrated that young people prefer health information through ICTs rather than through printed materials $[5,6]$.

\section{Prevention and Treatment Strategies-Serious Games}

A novel ICT approach is "serious games," which is a term used for digital games that are designed for educational and training purposes [7]. Serious gaming is a promising method to convey health-related information and promote change in health-related behaviors because of its exciting, enjoyable, and intrinsically motivational nature [8-13]. Several studies have investigated the effects of serious games on health-related outcomes like nutrition knowledge, dietary behavior, physical activity, and body mass index [14-20]. A randomized controlled trial observed that 10-12-year-old children who played video games significantly increased fruits and vegetable consumption compared with the control group, who played serious games on websites [21]. A systematic review showed that most studies achieved positive results using video games in the prevention and treatment of obesity in children and adolescents. The authors emphasized that video games provide an additional and supporting element in preventing and treating obesity along with the potential to increase treatment compliance and to promote success [22]. The "Alien Health Game," a nutrition instruction game, increased short-term nutrition knowledge among primary school children [13]. Owing to the high acceptance and widespread usage of digital games, children and adolescents seem to be a suitable target group for the serious gaming approach. Nevertheless, exposure to electronic gameplay may be associated with overweight and obesity because of its potential to increase sedentary behavior and consumption of energy-dense foods and beverages [23,24]. In addition, general and especially excessive use of digital devices is associated with negative effects such as school difficulties, sleep disturbance, depression, and Attention-Deficit/Hyperactivity Disorder [24-26]. Nowadays, serious and exergames are developed to overcome the adverse effects of gameplay by education combined with entertainment, known as "edutainment" [11,27]. Serious games may enable health educators to integrate health education into already existing game-based activities.

\section{Aim}

The objective of this survey was to gather information about the preferences, motives, and needs of children and adolescents regarding nutrition and digital games. The results of this survey are intended to be used for the development of a serious nutrition game tailored to children and adolescents.

\section{Methods}

\section{Design and Protocol}

The Ethical Committee of the Faculty of Medicine at the Technical University of Munich and the Rosenheim School Board approved this survey, which was conducted in 6 secondary schools in the city and administrative district of Rosenheim (Bavaria, Germany) between June 2016 and July 2017. We obtained written consent from parents or legal guardians of each participant.

\section{Recruitment and Procedure}

The Rosenheim School Board invited 23 secondary schools to participate in the survey. Children and adolescents were recruited by school teachers. We conducted the survey under standardized conditions according to a detailed survey protocol, which was executed by the study team. Each participant received a hard copy of the questionnaire. The study team read the introduction aloud, after which participants completed the questionnaire on their own. Children and adolescents who were not given parental permission to participate received a nutrition quiz. The maximum time for completing the questionnaire was 45 minutes, which corresponds to 1 classroom hour.

\section{Questionnaire: Development and Design}

An interdisciplinary team of nutritionists, economists, sociologists, and computer scientists developed a target group-specific questionnaire. The preliminary questionnaire was pretested for ease-of-use and understandability by a subset of 26 individuals aged 14-17 years. The final questionnaire was designed using EvaSys V7.0 (2101). The introduction included information regarding the research project, data protection, voluntary participation, and contained instructions for completing the questionnaire. The main part consisted of questions referring to 3 different subjects-nutrition (16 questions), digital games (21 questions), and personal characteristics (6 questions). The nutrition questions referred to nutritional communication, behavior, and knowledge and focused on preferences, motives, and needs. The area on digital games consisted of questions on preferences, motives, and needs regarding gaming behavior in general and digital gaming behavior in particular. To design a target group-tailored serious game, questions concerning the design of a digital game were also asked. In addition, we obtained sociodemographic (age, sex, and home environment) and self-reported anthropometric data (weight and height). The mean value for weight and height was calculated for participants who provided ranges for these values. The literature indicates that self-reporting of weight and height is an appropriate and reliable assessment method among 
adolescents and young adults compared with measured anthropometric data [28,29]. To maintain the attention and motivation of respondents, introductory questions were used. In addition, the filter question "Do you play digital games (smartphone, computer, console, apps)?" was asked to ensure that subsequent questions were answered only by participants who actually play digital games. The majority of the questions were closed and semiended with single or multiple-choice answer options; however, the questionnaire also contained a few open-ended questions. The questions were short, unidimensional, and easy to understand. To avoid influencing the response behavior, questions were designed to be neutral and target group-specific. Furthermore, a "do not know" or "no answer applies" option was mostly provided to prevent incorrect responses and remove pressure. Furthermore, questions were formulated in a way to avoid social desirability.

\section{Statistical Analyses}

Data were initially checked for integrity and plausibility. Respondents with $\geq 8$ unanswered or invalid questions were excluded. Therefore, the number of respondents varied from question to question. Furthermore, the statistical analysis was focused on selected questions, which are directly associated with the game development. In total, 21 questions were considered for the underlying analysis (Multimedia Appendix 1). The descriptive data analysis (frequencies and percentages) was performed using Microsoft Excel 2013 (Microsoft Corp) and SPSS version 24 (IBM Corp).

\section{Results}

\section{Participants' Characteristics}

In total, 293 German-speaking children and adolescents (137 girls and 156 boys) from the 7th to 8th grade who were not affected by writing disabilities participated in this study. Table 1 presents participants' demographic and anthropometric characteristics. Children and adolescents (137/293, 46.8\% girls) aged, on average, 14.7 (SD 1.2) years. Weight ranged 30.0-120.0 (mean 60.2 [SD 13.2]) kg, while height varied between $1.4 \mathrm{~m}$ and 2.0 (mean 1.7 [SD 0.1]) m. Most respondents (278/293, $94.9 \%$ ) reported that they live "at home."

\section{Digital and Nondigital Sources of Nutritional Information}

Table 2 shows sources of digital and nondigital nutritional information that are currently used, as well as additionally desired by respondents. More than one-half of the participants $(166 / 291,57.0 \%)$ reported using the internet as a digital information source. In total, $71.8 \%$ (209/291) participants indicated obtaining nondigital nutritional information from parents and adults in general. In contrast, most participants wanted to receive additional nutritional information through apps $(49 / 274,17.9 \%)$ and school education (108/274, 39.4\%). Fewer than $10 \%(23 / 291,7.9 \%)$ of participants reported currently using or wanting to use additionally (19/274, 6.9\%) digital games to familiarize themselves with nutrition knowledge. Twice as many boys $(16 / 156,10.3 \%)$ as girls $(7 / 137$, $5.1 \%$ ) used digital games for nutritional information; however, this gender-specific difference was not observed for any other currently used information source.

Table 1. Participants' characteristics $(\mathrm{N}=293)$.

\begin{tabular}{|c|c|c|c|}
\hline Variable & Participants, n (\%) & Participants, mean (SD) & Minimum, maximum \\
\hline \multicolumn{4}{|l|}{ Age (years) ${ }^{a}$} \\
\hline $12-14$ & $148(50.5)$ & $N / A^{b}$ & N/A \\
\hline $15-17$ & $134(45.7)$ & N/A & N/A \\
\hline 18 & $11(3.8)$ & N/A & N/A \\
\hline \multicolumn{4}{|l|}{ Sex } \\
\hline Girls & $137(46.8)$ & N/A & N/A \\
\hline Boys & $156(53.2)$ & N/A & N/A \\
\hline \multicolumn{4}{|c|}{ Anthropometric data } \\
\hline Weight $(\mathrm{kg})$ & $276(94.2)$ & $60.2(13.2)$ & $30.0,120.0$ \\
\hline Height (m) & $289(98.6)$ & $1.7(0.1)$ & $1.4,2.0$ \\
\hline \multicolumn{4}{|c|}{ Home environment } \\
\hline At home & $278(94.9)$ & N/A & N/A \\
\hline Alone & $2(0.7)$ & N/A & N/A \\
\hline Other & $13(4.4)$ & N/A & N/A \\
\hline
\end{tabular}

${ }^{\mathrm{a}}$ Participants: mean 14.7 (SD 1.2); minimum 12, maximum 18.

${ }^{b}$ N/A: not applicable. 
Table 2. Sources of nutritional information.

\begin{tabular}{|c|c|c|c|}
\hline Nutritional information source ${ }^{\mathrm{a}}$ & All, n (\%) & Girls, n (\%) & Boys, $\mathrm{n}(\%)$ \\
\hline \multicolumn{4}{|l|}{ Currently used $^{b}$} \\
\hline \multicolumn{4}{|l|}{ Digital } \\
\hline Television & $97(33.3)$ & $39(28.7)$ & $58(37.4)$ \\
\hline Internet & $166(57.0)$ & $79(58.1)$ & $87(56.1)$ \\
\hline Social networks & $78(26.8)$ & $42(30.9)$ & $36(23.2)$ \\
\hline Apps & $33(11.3)$ & $15(10.9)$ & $18(11.5)$ \\
\hline Digital games & $23(7.9)$ & $7(5.1)$ & $16(10.3)$ \\
\hline \multicolumn{4}{|l|}{ Nondigital } \\
\hline School & $161(55.3)$ & $76(55.5)$ & $85(54.5)$ \\
\hline Parents and adults & $209(71.8)$ & $100(73.0)$ & $109(69.9)$ \\
\hline Friends & $54(18.6)$ & $32(23.4)$ & $22(14.1)$ \\
\hline Books \& newspapers & $74(25.4)$ & $44(32.1)$ & $30(19.2)$ \\
\hline \multicolumn{4}{|l|}{ Other } \\
\hline Unconscious & $51(17.5)$ & $19(13.9)$ & $32(20.5)$ \\
\hline No answer applies & $13(4.5)$ & $4(2.9)$ & $9(5.8)$ \\
\hline \multicolumn{4}{|l|}{ Additionally desired $^{\mathrm{c}}$} \\
\hline \multicolumn{4}{|l|}{ Digital } \\
\hline Television & 45 (16.4) & $19(14.5)$ & $26(18.2)$ \\
\hline Internet & $46(16.8)$ & $22(16.8)$ & $24(16.8)$ \\
\hline Social networks & $34(12.4)$ & $15(11.5)$ & $19(13.3)$ \\
\hline Apps & $49(17.9)$ & $29(22.1)$ & $20(14.0)$ \\
\hline Digital games & $19(6.9)$ & $10(7.6)$ & $9(6.3)$ \\
\hline \multicolumn{4}{|l|}{ Nondigital } \\
\hline School & $108(39.4)$ & $43(32.8)$ & $65(45.5)$ \\
\hline Parents \& adults & $46(16.8)$ & $23(17.6)$ & $23(16.1)$ \\
\hline Friends & $17(6.2)$ & $12(9.2)$ & $5(3.5)$ \\
\hline Books \& newspapers & $31(11.3)$ & $22(16.8)$ & $9(6.3)$ \\
\hline \multicolumn{4}{|l|}{ Other } \\
\hline Unconscious & $29(10.6)$ & $15(11.5)$ & $14(9.8)$ \\
\hline No answer applies & $74(27.0)$ & $30(22.9)$ & $44(30.8)$ \\
\hline
\end{tabular}

\footnotetext{
${ }^{\mathrm{a}}$ Multiple responses allowed.

${ }^{\mathrm{b}}$ Where are you informed about nutrition?/Where do you inform yourself about nutrition?; n (\%)=291 (100).

${ }^{\mathrm{c}}$ Where do you want to be additionally informed about nutrition?; $\mathrm{n}(\%)=274$ (100).
}

\section{Knowledge About Nutrition}

In total, 4 questions were asked to evaluate the participants' nutrition knowledge (Table 3). Less than one-fourth of respondents $(66 / 290,22.8 \%)$ answered the question regarding the daily recommended fruits and vegetable consumption according to the German Nutrition Society (DGE) correctly. The common response to the question "Do you know what a food pyramid is?" was "Yes" (260/293, 88.7\%). Almost three-fourths $(210 / 291,72.2 \%)$ of the survey population correctly indicated that fish should be eaten once or twice per week. In total, 24.7\% (72/291) participants responded incorrectly regarding the calorie content of $100 \mathrm{~g}$ of sugar; almost one-half of children and adolescents $(145 / 291,49.8 \%)$ replied with "I don't know." Moreover, 10.3\% (30/290) and 18.2\% (53/291) reported not knowing the correct answer regarding recommendations of daily fruits and vegetable or fish consumption. Overall, only 5.5\% (16/290) of participants correctly answered all 4 questions regarding nutrition knowledge. 
Table 3. Nutrition knowledge in children and adolescents.

\begin{tabular}{|c|c|c|c|c|c|c|c|c|c|c|}
\hline \multirow[t]{2}{*}{ Question $^{\mathrm{a}}$} & \multirow[t]{2}{*}{$\mathrm{n}(\%)$} & \multicolumn{3}{|c|}{ Correct answer } & \multicolumn{3}{|c|}{ Incorrect answer } & \multicolumn{3}{|c|}{ Answer "I don't know" } \\
\hline & & $\begin{array}{l}\text { All, } \\
\text { n (\%) }\end{array}$ & $\begin{array}{l}\text { Girls, } \\
\mathrm{n}(\%)\end{array}$ & $\begin{array}{l}\text { Boys, } \\
\text { n (\%) }\end{array}$ & $\begin{array}{l}\text { All, } \\
\text { n (\%) }\end{array}$ & $\begin{array}{l}\text { Girls, } \\
\text { n (\%) }\end{array}$ & $\begin{array}{l}\text { Boys, } \\
\text { n (\%) }\end{array}$ & $\begin{array}{l}\text { All, } \\
\text { n }(\%)\end{array}$ & $\begin{array}{l}\text { Girls, } \\
\text { n (\%) }\end{array}$ & $\begin{array}{l}\text { Boys, } \\
\text { n (\%) }\end{array}$ \\
\hline $\begin{array}{l}\text { How many por- } \\
\text { tions of fruits and } \\
\text { vegetables should } \\
\text { be eaten (portion } \\
\text { = a handful) each } \\
\text { day? }\end{array}$ & $290(100)$ & $66(22.8)$ & $31(23.1)$ & $35(22.4)$ & $194(66.9)$ & $87(64.9)$ & 107 (68.6) & $30(10.3)$ & $16(11.9)$ & $14(9.0)$ \\
\hline $\begin{array}{l}\text { Do you know } \\
\text { what a food pyra- } \\
\text { mid is? }\end{array}$ & $293(100)$ & $260(88.7)$ & $129(94.2)$ & $131(84.0)$ & 33 (11.3) & $8(5.8)$ & $25(16.0)$ & $\mathrm{N} / \mathrm{A}^{\mathrm{b}}$ & N/A & N/A \\
\hline $\begin{array}{l}\text { How often should } \\
\text { fish be eaten each } \\
\text { week? }\end{array}$ & $291(100)$ & $210(72.2)$ & $101(73.7)$ & $109(70.8)$ & $28(9.6)$ & $11(8.0)$ & $17(11.0)$ & $53(18.2)$ & $25(18.3)$ & $28(18.2)$ \\
\hline $\begin{array}{l}\text { How many calo- } \\
\text { ries [kcal] are in } \\
100 \mathrm{~g} \text { of sugar? }\end{array}$ & $291(100)$ & $74(25.4)$ & $24(17.7)$ & $50(32.3)$ & $72(24.7)$ & $34(25.0)$ & $38(24.5)$ & 145 (49.8) & 78 (57.4) & $67(43.2)$ \\
\hline
\end{tabular}

${ }^{\mathrm{a}}$ Single response allowed.

${ }^{\mathrm{b}} \mathrm{N} / \mathrm{A}$ : not applicable.

\section{Digital Gameplay: Preferences, Motives, and Needs}

Multimedia Appendix 2 presents motives, behavior, and preferences regarding digital games. More than $80 \%$ (242/283, $85.5 \%$ ) of the survey population reported playing digital games. Children and adolescents primarily play digital games if they were in the mood $(209 / 282,74.1 \%)$ or if they are bored $(164 / 282,58.2 \%)$, while $8.5 \%(24 / 282)$ reported happiness or sadness $(15 / 282,5.3 \%)$ as motivators for digital gameplay. More boys than girls indicated playing digital games when they felt like gaming or when they were happy. Children and adolescents often play digital games if they were alone at home (117/282, $41.5 \%)$ or stay with friends $(54 / 282,19.2 \%)$, while boys reported this behavior 2-3 times more often than girls. Playing time was observed to be dependent on the digital device. While most participants play digital games continuously for up to 30 minutes on a smartphone or tablet $(151 / 227,66.5 \%)$, less than half $(57 / 209,27.3 \%)$ play for up to 30 minutes on a personal computer (PC) or console. Participants reported playing digital games $\geq 1$ hour on $P C$ or consoles $(116 / 209,55.5 \%)$, which was 3 times more often than those playing digital games for the same amount of time on smartphones or tablets $(41 / 227,18.1 \%)$. Compared with female participants $(6 / 79,7.6 \%)$, male children and adolescents were far more likely to play digital games for $>1$ hour $(47 / 130,36.2 \%)$. A similar trend could be detected for a gaming duration lasting 1 hour. The most common answer regarding gaming frequency on any device was daily, with differences observed between girls and boys. In addition to the motives behind digital gameplay and the behavior itself, the questionnaire also asked about gaming preferences. More than one-half of the survey population preferred that teammates in a digital nutrition game are friends $(191 / 286,66.8 \%)$ or individuals with similarities, such as hobbies or eating behaviors (203/286, 71.0\%); however, some participants 7.4\% (21/286) favored playing without a team. Almost one-half of children and adolescents reported enjoying digital gameplay with $\leq 5$ players $(116 / 255,45.5 \%)$, and $22.8 \%(58 / 255)$ of participants liked playing alone. Close to one-half of participants (119/277, $43.0 \%$ ) preferred an older or same-aged human as a game character, while $19.1 \%(53 / 277)$ preferred a fantasy character. The main proportion of the survey population reported that they prefer learning about nutrition through a quiz $(157 / 287,54.7 \%)$ or by solving tasks $(123 / 287,42.9 \%)$. Some participants $12.9 \%$ (37/287) did not want to learn anything in a digital nutrition game, with boys about 3 times more likely to report this answer $(29 / 151,19.2 \%)$ than girls $(8 / 136,5.9 \%)$.

\section{Discussion}

\section{Nutrition Knowledge in Children and Adolescents}

This survey suggests that nutrition knowledge in children and adolescents may be limited. Only 6\% (16/290) correctly answered the 4 questions regarding nutrition knowledge. Moreover, one-fourth $(66 / 290,22.8 \%)$ of participants knew that eating fruits and vegetables 5 times per day is recommended, and nearly the same number $(74 / 291,25.4 \%)$ correctly answered questions about the calorie content of sugar. These findings are consistent with the results of a recent study by the German Nutrition Society, which indicated that around 50\% of German adolescents are inadequately informed about the components of a healthy diet [30]. The National Pupil Survey (2013) revealed that only one-half of children and adolescents aged 11-16 years correctly answered a question regarding the recommendation for daily fish intake [31]. This survey indicates that $>70 \%$ of participants knew that fish should be eaten once or twice per week. As evidenced by the National Pupil Survey, 88\% of adolescents know that 5 portions of fruits and vegetables should be eaten each day [31]. Epidemiological data have demonstrated that knowledge about nutritional recommendations as well as the intake of fruits and vegetables has to be improved in German adolescents. A German survey revealed that only $25 \%-29 \%$ of girls and $16 \%-18 \%$ of boys met the fruits or vegetable intake 
recommendation [32]. It should be mentioned that this survey provides no representative data of nutrition knowledge among children and adolescents. Furthermore, it cannot be ruled out that respondents affirmed the question without even having knowledge of it. Hence, the 4 questions about nutrition knowledge can only provide a small impression about respondents' nutrition knowledge. In addition, it is noteworthy that many factors have an impact on children's and adolescents' nutrition knowledge. According to this survey, the majority of children and adolescents (72\%) consult their parents or adults regarding nutrition. Wansink stated that a "home's nutritional gatekeeper is the biggest food influence in the nutrition life" of all family members [33]. The findings of Qian et al showed that children with low parent education level tend to have a less comprehensive nutrition knowledge than children from parents who are more highly educated [34]. As the survey was only conducted in secondary schools, it could be assumed that the education level of parents might have been rather low. Further literature indicates that nutritional education of parents can be effective in improving children's diet $[35,36]$. A recent systematic review of parent-targeted, in-home interventions resulted in a small but significant increase in fruits consumption in children [35]. These facts need to be considered, as nearly $95 \%$ of children and adolescents in this survey lived at home. Findings regarding the effectiveness of nutritional education programs on dietary knowledge and food behaviors are controversial [37]. A study showed that students aged 14-19 years significantly improved their nutrition knowledge after attending a nutritional course at school [38]. A 5-day physical activity and nutritional intervention program in children with overweight and obesity resulted in higher rates of physical activity, as well as in a reduction of consumed sugar and sweets [39]. Moreover, reviews demonstrated that nutritional education could be effective in improving healthy eating behaviors [40]; in contrast, a cross-sectional survey revealed that the "knowledge of healthy foods does not translate to healthy snack consumption" [41]. By improving nutrition knowledge and health attitudes children and adolescents may develop a healthier lifestyle and, thus, would be at lower risk of becoming overweight or obese [38].

\section{Implications for Game Design}

This study shows that more than one-half of children and adolescents would like to receive nutritional information through digital games. The majority stated that they would like to learn about nutrition in a digital game by playing a quiz $(55 \%)$ or by solving tasks (43\%). Therefore, different types of quizzes should be considered in the development of a nutrition game [42]. A recent study in children investigated the delivery of nutritional information through a gaming app and demonstrated that learning of nutritional information was improved with repeated exposure [43]. To convey knowledge effectively through a game, different elements should be considered in the game design [42]. Many participants (43\%) reported preferring a fantasy character as a game character. These findings are similar to the results of a survey about serious games conducted among 465 Asian pharmacy students; most participants (60\%) preferred a fantasy, medieval, and mythical setting, while $41 \%$ wanted an adventure storyline [44]. For example, the "Move2Play" game contains an avatar which can be personalized by users. A small study showed that adolescents enjoyed customizing their avatar [45]. It is also worth mentioning that children and adolescents in this survey preferred playing digital games with friends $(191 / 286,66.8 \%)$ and only one-fifth of participants $(58 / 255,22.8 \%)$ played digital games by themselves. The literature confirms that digital gaming has a great social value. In a survey on video gameplay among 1254 US 7th- and 8 th-grade students, only $18 \%$ of male and $12 \%$ of female children and adolescents indicated that they always play alone [46]. In addition, digital gaming as a social activity was confirmed in a focus group of 42 male adolescents [46]. Considering these findings, players should be given an opportunity to create social groups in a game [42]. Furthermore, social components, such as chat interaction, group profiles, and social games or challenges, should be implemented [42].

\section{Digital Gameplay_Preferences, Motives, and Needs}

This survey data show that $>85 \%$ of children and adolescents play digital games. According to the survey by Olson et al, only $6 \%$ of children and adolescents did not play any digital games in the 6 months prior to the survey [46]; these results confirm that children and adolescents are frequent users of digital devices [47]. Adolescents aged 15-18 years spend on average 22 minutes per day on video gaming on cell phones, and 31 minutes per day on consoles [47]. Furthermore, a German survey showed that two-thirds of participants aged $12-19$ years $(n=1200)$ played digital games (smartphone, PC [offline], console, online, and tablet) regularly (daily or several times a week), whereas only $8 \%$ never played digital games [48]. Regarding the frequency of digital gameplay, these results are similar to the current findings. Almost two-thirds of participants specified playing digital games daily or weekly on smartphones or tablets, and more than two-thirds played on a PC or console. The use of educational games as a viable teaching strategy can promote enjoyment and, therefore, may enhance the retention of information in the long-term [12]. In contrast, excessive use of digital games can generate negative health effects in children and adolescents [23]. Consequently, there is an ongoing debate as to whether electronic gameplay is a "health hazard" or a "health promoter" [49]. The question of why young people play digital games is also addressed in this survey. Most children and adolescents have an emotionally induced digital gameplay experience and primarily replied to the question "When do you often play digital games?" with "pleasure" and "boredom." Olson et al showed that $45 \%$ of male and $29 \%$ of female participants said that they played to "To get my anger out," while $25 \%$ of boys and $11 \%$ of girls selected the answer "cope with anger" [46,50]. Negative emotions, such as "sadness," were only reported by around 5\% of young people in this survey, whereas the answer option "anger" was not present within this questionnaire. The fact that most young people play digital games when they are in a positive mood could be exploited to transfer knowledge playfully and entertainingly through digital games.

\section{Serious Games-Serious Design}

Although there are a growing market supply and demand for health-related games, little is known about game design aspects 
and preferences, motives, and needs of children and adolescents regarding digital nutrition games [51]. It is important to emphasize that qualitative research (eg, interviews) prior to game design is critical [52]. Consideration of the "needs, interests, perspectives, and preferences" of the target group in the development of health games may result in better targeted games [52]. Furthermore, collaborations with health professionals from an early design stage are necessary, both to ensure that the content is accurate and to have the game validated from a clinical viewpoint. The target group needs to be involved, especially to improve the usability. It is well known that health promotion and disease prevention programs suffer from poor adherence and compliance by participants, often because they are designed without addressing the target group $[14,53]$. This also applies to the field of health games. In their recently published review, $\mathrm{Lu}$ and Kharrazi examined almost 2000 health-related games (from 1983 to 2016) for usability and concluded that one of the main limitations is the lack in customization and feedback [54].

\section{Digital Games for Nutritional Education at Schools}

Furthermore, it has to be noted that most children and adolescents like to receive additional nutritional information through apps or at school. According to a study of 505 American teachers, more than one-half (55\%) reported using games as an educational element in school teaching [55]. The advantage of serious games is to educate the target group through entertaining, enjoyable, and intrinsically motivating game elements and experiences $[11,27]$. Therefore, a serious nutrition game may be a suitable, educative method to impart nutrition knowledge and to promote healthy dietary behaviors in children and adolescents.

\section{Limitations}

This survey revealed findings about digital nutrition games among children and adolescents, yet it has some limitations. The survey was conducted in one school area and type. Therefore, it is limited by sample size and homogeneity. Moreover, present findings are not representative, especially concerning nutrition knowledge, which was assessed on the basis of 4 questions. Furthermore, it cannot be ruled out that the participation rate, which cannot be calculated owing to missing data (invited vs participated children and adolescents), is biased by the motivation and engagement of teachers, parents, and participants themselves. The nonvalidated questionnaire used in the survey was internally generated to obtain all the relevant information for a target group-specific game design. As the age of participants is only available as life years without months, no appropriate weight classification for children and adolescents (percentiles/z-scores) could be calculated. The results are further limited owing to missing information about parental education level. Future research should address more diverse survey populations across entire Germany, providing further insights and expanding the generalizability.

\section{Conclusions}

Results revealed that children and adolescents are interested in nutritional information. Present findings support previous surveys that there is a lack of nutrition knowledge in this target group. Children and adolescents stated a preference for apps and school education in order to receive additional nutritional information. Furthermore, the target group was interested in digital games as well. Therefore, such preferences and interests could be implemented in an educational app, for example, for schools to increase nutrition knowledge and to improve dietary behavior.

\section{Acknowledgments}

The authors acknowledge all teachers and participants of the cooperating schools for their collaboration and contributions. In addition, we mention the valuable contribution of all cooperation partners of the Technical University of Munich, with special regard to Gudrun Klinker, Jutta Roosen, Susanne Ihsen, David A. Plecher, Bernhard Mohr, Katharina Scheibl, and Christoph Lingl. Special thanks go to Lynne Stecher for statistical advice.

This work has been funded by the enable Cluster funded by the German Federal Ministry of Education and Research (funding number: 01EA1409H, enable publication number: 014).

\section{Conflicts of Interest}

None declared.

\section{Multimedia Appendix 1}

Questionnaire excerpt from Holzmann et al (Digital Gaming for Nutritional Education).

[PDF File (Adobe PDF File), 193KB-Multimedia Appendix 1]

\section{Multimedia Appendix 2}

Table from Holzmann et al (Digital Gameplay: Motives, Behavior, and Preferences).

[PDF File (Adobe PDF File), 115KB-Multimedia Appendix 2]

\section{References}


1. Swinburn BA, Caterson I, Seidell JC, James WPT. Diet, nutrition and the prevention of excess weight gain and obesity. Public Health Nutr 2004 Feb;7(1A):123-146. [Medline: 14972057]

2. Kurth B, Schaffrath Rosario A. [Overweight and obesity in children and adolescents in Germany]. Bundesgesundheitsblatt Gesundheitsforschung Gesundheitsschutz 2010 Jul;53(7):643-652. [doi: 10.1007/s00103-010-1083-2] [Medline: 20631974]

3. Abarca-Gómez L, Abdeen Z, Hamid Z, Abu-Rmeileh N, Acosta-Cazares B, Acuin C, et al. Worldwide trends in body-mass index, underweight, overweight, and obesity from 1975 to 2016: a pooled analysis of 2416 population-based measurement studies in 128.9 million children, adolescents, and adults. Lancet 2017;390(10113):P2627-P2642. [doi: 10.1016/S0140-6736(17)32129-3]

4. World Health Organization. World health statistics 2018: monitoring health for the SDGs, sustainable development goals. In: World health statistics. Geneva: World Health Organization; 2018:1-86.

5. Casazza K, Ciccazzo M. The method of delivery of nutrition and physical activity information may play a role in eliciting behavior changes in adolescents. Eat Behav 2007 Jan;8(1):73-82. [doi: 10.1016/j.eatbeh.2006.01.007] [Medline: 17174854]

6. Long JD, Stevens KR. Using technology to promote self-efficacy for healthy eating in adolescents. J Nurs Scholarsh 2004;36(2):134-139. [Medline: 15227760]

7. Annetta LA. The "I's" have it: A framework for serious educational game design. Rev Gen Psycholref 2010;14(2):105-112. [doi: $10.1037 / \mathrm{a} 0018985]$

8. Ingadottir B, Blondal K, Thue D, Zoega S, Thylen I, Jaarsma T. Development, Usability, and Efficacy of a Serious Game to Help Patients Learn About Pain Management After Surgery: An Evaluation Study. JMIR Serious Games 2017 May 10;5(2):e10 [FREE Full text] [doi: 10.2196/games.6894] [Medline: 28490419]

9. Kato PM. Video games in health care: Closing the gap. Rev Gen Psychol 2010;14(2):113-121. [doi: 10.1037/a0019441]

10. Baranowski T, Blumberg F, Buday R, DeSmet A, Fiellin LE, Green CS, et al. Games for Health for Children-Current Status and Needed Research. Games Health J 2016 Feb;5(1):1-12 [FREE Full text] [doi: 10.1089/g4h.2015.0026] [Medline: 26262772]

11. Baranowski T, Buday R, Thompson DI, Baranowski J. Playing for real: video games and stories for health-related behavior change. Am J Prev Med 2008 Jan;34(1):74-82 [FREE Full text] [doi: 10.1016/j.amepre.2007.09.027] [Medline: 18083454]

12. Blakely G, Skirton H, Cooper S, Allum P, Nelmes P. Educational gaming in the health sciences: systematic review. J Adv Nurs 2009 Feb;65(2):259-269. [doi: 10.1111/j.1365-2648.2008.04843.x] [Medline: 19032512]

13. Hermans RCJ, van den Broek N, Nederkoorn C, Otten R, Ruiter ELM, Johnson-Glenberg MC. Feed the Alien! The Effects of a Nutrition Instruction Game on Children's Nutritional Knowledge and Food Intake. Games Health J 2018 Jun;7(3):164-174. [doi: 10.1089/g4h.2017.0055] [Medline: 29634366]

14. DeSmet A, Van Ryckeghem D, Compernolle S, Baranowski T, Thompson D, Crombez G, et al. A meta-analysis of serious digital games for healthy lifestyle promotion. Prev Med 2014 Dec;69:95-107 [FREE Full text] [doi: 10.1016/j.ypmed.2014.08.026] [Medline: 25172024]

15. Amaro S, Viggiano A, Di Costanzo A, Madeo I, Viggiano A, Baccari ME, et al. Kalèdo, a new educational board-game, gives nutritional rudiments and encourages healthy eating in children: a pilot cluster randomized trial. Eur J Pediatr 2006 Sep;165(9):630-635. [doi: 10.1007/s00431-006-0153-9] [Medline: $\underline{16733670]}$

16. Blackburne T, Rodriguez A, Johnstone SJ. A Serious Game to Increase Healthy Food Consumption in Overweight or Obese Adults: Randomized Controlled Trial. JMIR Serious Games 2016 Jul 13;4(2):e10 [FREE Full text] [doi: 10.2196/games.5708] [Medline: 27417192]

17. Primack BA, Carroll MV, McNamara M, Klem ML, King B, Rich M, et al. Role of video games in improving health-related outcomes: a systematic review. Am J Prev Med 2012 Jun;42(6):630-638 [FREE Full text] [doi: 10.1016/j.amepre.2012.02.023] [Medline: 22608382]

18. Ledoux T, Griffith M, Thompson D, Nguyen N, Watson K, Baranowski J, et al. An educational video game for nutrition of young people: Theory and design. Simul Gaming 2016 Aug;47(4):490-516 [FREE Full text] [doi: 10.1177/1046878116633331] [Medline: 27547019]

19. Ezezika O, Oh J, Edeagu N, Boyo W. Gamification of nutrition: A preliminary study on the impact of gamification on nutrition knowledge, attitude, and behaviour of adolescents in Nigeria. Nutr Health 2018 Sep;24(3):137-144. [doi: 10.1177/0260106018782211] [Medline: 29974803]

20. Joyner D, Wengreen HJ, Aguilar SS, Spruance LA, Morrill BA, Madden GJ. The FIT Game III: Reducing the Operating Expenses of a Game-Based Approach to Increasing Healthy Eating in Elementary Schools. Games Health J 2017 Apr;6(2):111-118 [FREE Full text] [doi: 10.1089/g4h.2016.0096] [Medline: 28375645]

21. Baranowski T, Baranowski J, Thompson D, Buday R, Jago R, Griffith MJ, et al. Video game play, child diet, and physical activity behavior change a randomized clinical trial. Am J Prev Med 2011 Jan;40(1):33-38 [FREE Full text] [doi: 10.1016/j.amepre.2010.09.029] [Medline: 21146765]

22. Mack I, Bayer C, Schäffeler N, Reiband N, Brölz E, Zurstiege G, et al. Chances and Limitations of Video Games in the Fight against Childhood Obesity-A Systematic Review. Eur Eat Disord Rev 2017 Dec;25(4):237-267. [doi: 10.1002/erv.2514] [Medline: 28467004]

23. Calvert SL, Staiano AE, Bond BJ. Electronic gaming and the obesity crisis. New Dir Child Adolesc Dev 2013;2013(139):51-57 [FREE Full text] [doi: 10.1002/cad.20031] [Medline: 23483693] 
24. Husarova D, Blinka L, Madarasova Geckova A, Sirucek J, van Dijk JP, Reijneveld SA. Do sleeping habits mediate the association between time spent on digital devices and school problems in adolescence? Eur J Public Health 2018 Dec 01;28(3):463-468. [doi: 10.1093/eurpub/ckx198] [Medline: 29177445]

25. Lemola S, Perkinson-Gloor N, Brand S, Dewald-Kaufmann JF, Grob A. Adolescents' electronic media use at night, sleep disturbance, and depressive symptoms in the smartphone age. J Youth Adolesc 2015 Feb;44(2):405-418. [doi:

10.1007/s10964-014-0176-x] [Medline: 25204836]

26. Radesky J. Digital Media and Symptoms of Attention-Deficit/Hyperactivity Disorder in Adolescents. JAMA 2018 Dec 17;320(3):237-239. [doi: 10.1001/jama.2018.8932] [Medline: 30027231]

27. Baranowski T, Baranowski J, Cullen KW, Marsh T, Islam N, Zakeri I, et al. Squire's Quest! Dietary outcome evaluation of a multimedia game. Am J Prev Med 2003 Jan;24(1):52-61. [Medline: 12554024]

28. Nikolaou CK, Hankey CR, Lean MEJ. Accuracy of on-line self-reported weights and heights by young adults. Eur J Public Health 2017 Dec 01;27(5):898-903. [doi: 10.1093/eurpub/ckx077] [Medline: 28633350]

29. Kee CC, Lim KH, Sumarni MG, Teh CH, Chan YY, Nuur Hafizah MI, et al. Validity of self-reported weight and height: a cross-sectional study among Malaysian adolescents. BMC Med Res Methodol 2017 Jun 02;17(1):85 [FREE Full text] [doi: 10.1186/s12874-017-0362-0] [Medline: 28577547]

30. Deutsche Gesellschaft für Ernährung e. V. Ernährungsbericht 2000. Frankfurt am Main, Germany: Deutsche Gesellschaft für Ernährung e V; 2000.

31. British Nutrition Foundation. National Pupil Survey 2014 UK Survey Results URL: http://tinyurl.com/yccpp9ex[WebCite Cache ID 72WJw3v4A]

32. Mensink G, Heseker H, Richter A, Stahl A, Vohmann C, Fischer J, et al. Ernährungsstudie als KiGGS-Modul (EsKiMo). Robert Koch-Institut, Epidemiologie und Gesundheitsberichterstattung 2007:1-137. [doi: 10.25646/477]

33. Wansink B. Nutritional gatekeepers and the 72\% solution. J Am Diet Assoc 2006 Sep;106(9):1324-1327. [doi: 10.1016/i.jada.2006.07.023] [Medline: 16963331]

34. Qian L, Zhang F, Newman IM, Shell DF, Du W. Effects of selected socio-demographic characteristics on nutrition knowledge and eating behavior of elementary students in two provinces in China. BMC Public Health 2017 Dec 14;18(1):21 [FREE Full text] [doi: 10.1186/s12889-017-4580-5] [Medline: 28709414]

35. Touyz LM, Wakefield CE, Grech AM, Quinn VF, Costa DSJ, Zhang FF, et al. Parent-targeted home-based interventions for increasing fruit and vegetable intake in children: a systematic review and meta-analysis. Nutr Rev $2018 \mathrm{Mar}$ 01;76(3):154-173. [doi: 10.1093/nutrit/nux066] [Medline: 29319789]

36. Johnson BJ, Zarnowiecki D, Hendrie GA, Mauch CE, Golley RK. How to reduce parental provision of unhealthy foods to 3- to 8-year-old children in the home environment? A systematic review utilizing the Behaviour Change Wheel framework. Obes Rev 2018 Oct;19(10):1359-1370. [doi: 10.1111/obr.12702] [Medline: $\underline{\text { 30092606] }}$

37. Worsley A. Nutrition knowledge and food consumption: can nutrition knowledge change food behaviour? Asia Pac J Clin Nutr 2002;11 Suppl 3:S579-S585 [FREE Full text] [Medline: 12492651]

38. Watson LC, Kwon J, Nichols D, Rew M. Evaluation of the Nutrition Knowledge, Attitudes, and Food Consumption Behaviors of High School Students Before and After Completion of a Nutrition Course. Fam Consum Sci Res J 2009 May 28;37(4):523-534. [doi: 10.1177/1077727X08329002]

39. Rauber SB, Castro HDO, Marinho A, Vicente JB, Ribeiro HL, Monteiro LZ, et al. Effects of a physical activity and nutritional intervention in overweight and obese children through an educational and recreational camp. Nutr Health 2018 Sep;24(3):145-152. [doi: 10.1177/0260106018771519] [Medline: 29893164]

40. Li X, Huang Y, Yin R, Pan C, Cai Y, Wang Z. Visualized nutrition education and dietary behavioral change: A systematic review and meta-analysis. Crit Rev Food Sci Nutr 2018 May 04:1-37. [doi: 10.1080/10408398.2018.1469466] [Medline: 29727198]

41. McArthur LH, Valentino A, Holbert D. Knowledge of healthy foods does not translate to healthy snack consumption among exercise science undergraduates. Nutr Health 2017 Jun;23(2):103-110. [doi: 10.1177/0260106017704796] [Medline: 28413923]

42. Schäfer H, Plecher D, Holzmann S, Groh G, Klinker G, Holzapfel C, et al. NUDGE - NUtritional, Digital Games in Enable. 2017 Presented at: PGW@CHI PLAY; 15 - 18 October 2017; Amsterdam, Netherlands p. 1-5.

43. Putnam MM, Richmond EM, Brunick KL, Wright CA, Calvert SL. Influence of a Character-Based App on Children's Learning of Nutritional Information: Should Apps Be Served with a Side of Media Characters? Games Health J 2018 Apr;7(2):121-126 [FREE Full text] [doi: 10.1089/g4h.2017.0116] [Medline: 29364706]

44. Chang HY, Wong LL, Yap KZ, Yap KY. Gaming Preferences, Motivations, and Experiences of Pharmacy Students in Asia. Games Health J 2016 Feb;5(1):40-49. [doi: 10.1089/g4h.2015.0028] [Medline: 26795233]

45. Bielik P, Tomlein M, Krátky P, Mitrík S, Barla M, Bieliková M. Move2Play: an innovative approach to encouraging people to be more physically active. 2012 Presented at: ACM SIGHIT International Health Informatics Symposium; 28 - 30 January 2012; Miami, FL, USA p. 28-30.

46. Olson C, Kutner L, Beresin E. Children and Video Games: How Much Do We Know? Psychiatr Times 2007;24(12) [FREE Full text] 
47. Rideout V, Foehr U, Roberts D. A Kaiser Family Foundation Study. 2010 Jan. Generation M2: Media in the Lives of 8- to 18-Year-Olds URL: https://kaiserfamilyfoundation.files.wordpress.com/2013/01/8010.pdf [accessed 2018-02-14] [WebCite Cache ID 6xDs6occC]

48. Feierabend S, Plankenhorn T, Rathgeb T. Medienpädagogischer Forschungsverbund Südwest. JIM 2016 Jugend, Information, (Multi-) Media URL: https://www.mpfs.de/fileadmin/files/Studien/JIM/2016/JIM Studie 2016.pdf[WebCite Cache ID 6xDsWBKJB]

49. Olson CK. The Video Game Debate: Are Electronic Games Health Hazards or Health Promoters? In: The Video Game Debate Unravelling the Physical, Social, and Psychological Effects of Video Games. New York, NY, USA: Routledge; 2015:1-204.

50. Olson CK. Children's motivations for video game play in the context of normal development. Rev Gen Psychol 2010;14(2):180-187. [doi: 10.1037/a0018984]

51. Brox E, Fernandez-Luque L, Tøllefsen T. Healthy Gaming - Video Game Design to promote Health. Appl Clin Inform 2011;2(2):128-142 [FREE Full text] [doi: 10.4338/ACI-2010-10-R-0060] [Medline: 23616865]

52. Thompson D. Talk to Me, Please!: The Importance of Qualitative Research to Games for Health. Games Health J 2014 Jun;3(3):117-118. [doi: 10.1089/g4h.2014.0023] [Medline: 26196170]

53. Peykari N, Tehrani FR, Eftekhari MB, Malekafzali H, Dejman M, Neot R, et al. A peer-based study on adolescence nutritional health: a lesson learned from Iran. J Pak Med Assoc 2011 Jun;61(6):549-554. [Medline: 22204208]

54. Lu AS, Kharrazi H. A State-of-the-Art Systematic Content Analysis of Games for Health. Games Health J 2018 Feb;7(1):1-15. [doi: 10.1089/g4h.2017.0095] [Medline: 29293368]

55. Takeuchi L, Vaala S. Games Learning. Level up learning: A national survey on teaching with digital games URL: http:/ /www.joanganzcooneycenter.org/wp-content/uploads/2014/10/jgcc leveluplearning final.pdf [accessed 2018-02-14] [WebCite Cache ID 6xDspAcO8]

\title{
Abbreviations \\ ICT: information and communication technology \\ PC: personal computer
}

\author{
Edited by G Eysenbach; submitted 02.03.18; peer-reviewed by I Mack, M Allman-Farinelli; comments to author 04.10.18; revised \\ version received 04.10.18; accepted 25.11.18; published 13.02.19 \\ Please cite as: \\ Holzmann SL, Dischl F, Schäfer H, Groh G, Hauner H, Holzapfel C \\ Digital Gaming for Nutritional Education: A Survey on Preferences, Motives, and Needs of Children and Adolescents \\ JMIR Form Res 2019;3(1):e10284 \\ URL: http://formative.jmir.org/2019/1/e10284/ \\ doi: $10.2196 / 10284$ \\ PMID: $\underline{30758290}$
}

(CSophie Laura Holzmann, Felicitas Dischl, Hanna Schäfer, Georg Groh, Hans Hauner, Christina Holzapfel. Originally published in JMIR Formative Research (http://formative.jmir.org), 13.02.2019. This is an open-access article distributed under the terms of the Creative Commons Attribution License (https://creativecommons.org/licenses/by/4.0/), which permits unrestricted use, distribution, and reproduction in any medium, provided the original work, first published in JMIR Formative Research, is properly cited. The complete bibliographic information, a link to the original publication on http://formative.jmir.org, as well as this copyright and license information must be included. 